Tohoku J. exp. Med., 1966, 90, 35-40

\title{
A Technique of Ileocystoplasty for Bladder Enlargement
}

\author{
Sentaro Shishito and Seigi Tsuchida \\ Department of Urology (Prof. S. Shishito), \\ Tohoku University School of Medicine, Sendai
}

\begin{abstract}
A new technique for ileocystoplasty is described. The abdomen is opened through an abdominal median incision, and approximately $25 \mathrm{~cm}$ of the ileum are isolated together with the mesentery attached to it. The isolated ileum is then bent into a U-shape and the ileal walls are incised and sutured so as to form an open bag. Following the incision of the bladder wall, this newly formed bag is anastomosed to the bladder. Thus, an enlarged bladder is artificially formed.

This technique was employed with success in four cases of contracted tuberculous bladder and in one cases of neurogenic bladder.
\end{abstract}

Ileocystoplasty by utilizing the ileal canal to increase the bladder capacity has been attempted since the end of the 19 th century. In 1923 , Scheele ${ }^{1}$ described the "loop" ileocystoplasty and the usefulness of this technique has since been demonstrated. At first, the unique indication was a contracted bladder, but in recent years ileocystoplasty has been utilized for the purpose of supplementing a defect appearing as a result of cystectomy and applied to the treatment of neurogenic bladder. Its indication is, thus, being gradually widened.

Nevertheless, Scheele's technique has still many unfavorable points. A loop of the intestinal canal is as a urinary reservoir so limited in diameter that the anastomosed area cannot be widened as much as desired. As a possible result, stenosis may occur in the anastomosed area, thereby causing the intestinal graft to act as a diverticulum. In order to solve this problem, Tasker ${ }^{2}$ introduced a new technique in 1953. In his new technique, exclusion of about $20 \mathrm{~cm}$ of the ileum is first performed in the same manner as in Scheele's method. The isolated intestinal canal is divided into two equal portions, each of which is opened longitudinally to make a flat graft. These are then united by an edge-toedge suture, making a rectangular patch. This flat patch is then stitched to the bladder wall, previously bisected by an elliptical incision at the apex of the bladder. Tasker's technique is called the "open flap method", for it makes a flat patch by cutting open the isolated intestine. On the basis of a similar idea, Goodwin et $a l .^{3}$ devised the "cup-patch" technique.

Prior to 1960 , we carried out ileocystoplasty exclusively by using Scheele's technique, but stenosis of the anastomosed area was encountered in several cases. Thereafter, we employed Tasker's method in almost all cases. However,

Received for publication, May 11, 1966. 
Tasker's method is too complicated. Therefore, we developed a new technique described below. Our experience with this technique which has been conducted since 1960 , proves that it is useful in leading patients a healthy life free from pre-operative complaints.

\section{Operation Technique}

The abdomen is opened through a median incision extending from the umbilicus down to the suprapubic region, and then a careful examination is made as to whether there is any adhesion of the intestinal canal. Next, as shown in Fig. 1, about 20 to $30 \mathrm{~cm}$ of the ileum, together with a part of mesentery are isolated; the continuity of the alimentary tract was restored by an end-to-end anastomosis. The length of the ileum to be isolated depends upon the capacity of the artificial bladder to be newly formed, but it should not exceed $30 \mathrm{~cm}$. In most cases, the artificial bladder with a capacity of $300 \mathrm{ml}$ or more can be prepared with an isolated ileum 20 to $25 \mathrm{~cm}$ in length. This procedure is quite the same as that described by Scheele. The inner cavity of the isolated ileum is washed with a solution of antibiotic substances in order to prevent any infection by intraintestinal bacteria. The isolated ileum thus treated is bent in the shape of an inverted U, as shown in Fig. 2, and the serous membranes are joined by a nodular suture using fine silk thread or chromic catgut at the inner edges of the U-shaped ileum. Subsequently, as shown in Fig. 3, an incision is made on the serous membrane along the previously sutured inner edge in order to open the intestinal canal longitudinally. At this stage of operation bleeding can be lessened by loosely clamping, with an intestinal forceps, the inferior mesentery attached to the isolated intestinal canal. If bleeding still persists even after such hemostatic procedure, ligation should be done on the spot for hemostasis,

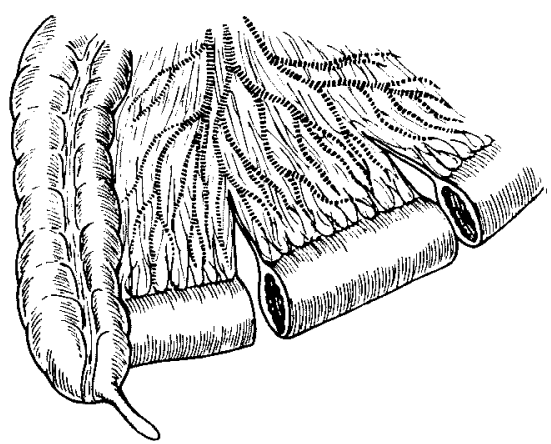

Fig. 1.

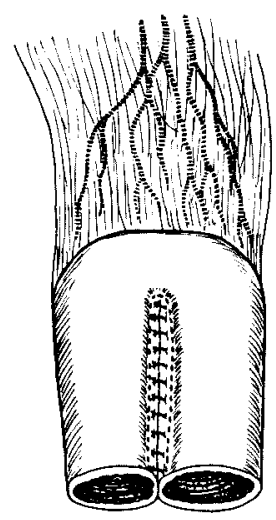

Fig. 2.

Fig. 1. Isolation of a portion of the ileum $20 \sim 30 \mathrm{~cm}$ in length.

Fig. 2. Isolated ileum bent into U-shape and sutured. 


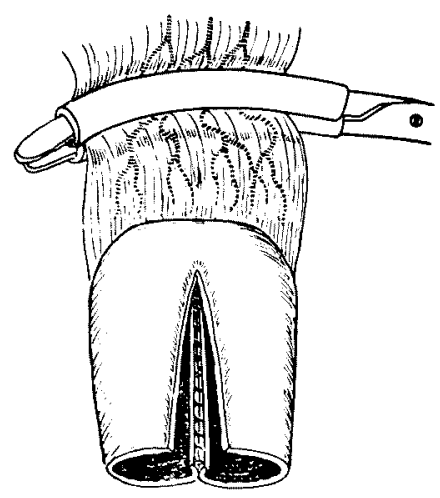

Fig. 3.

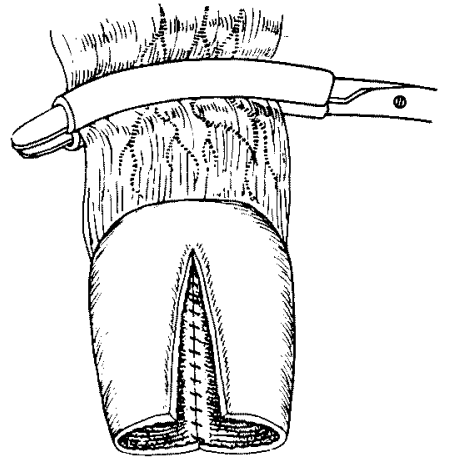

Fig. 4.

Fig. 3. Ileal segment incised on the serous membrane.

Fig. 4. Uninterrupted suturing of the mucous membranes of the ileum.

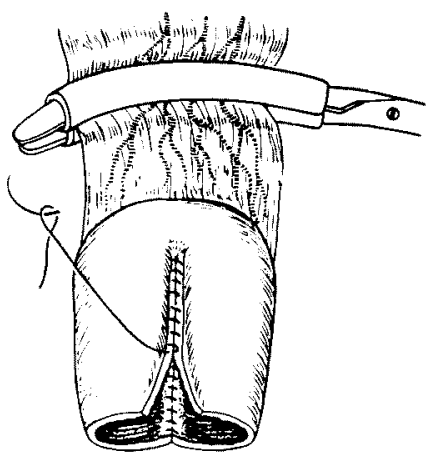

Fig. 5.

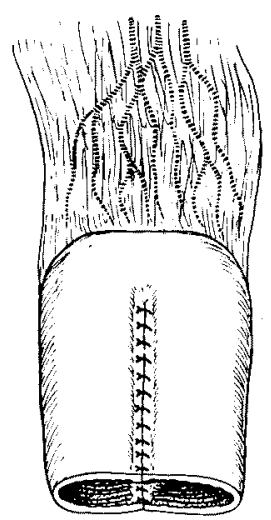

Fig. 6 .

Fig. 5. Suturing of the forehand intestinal walls.

Fig. 6. Completed bag made from ileal segment.

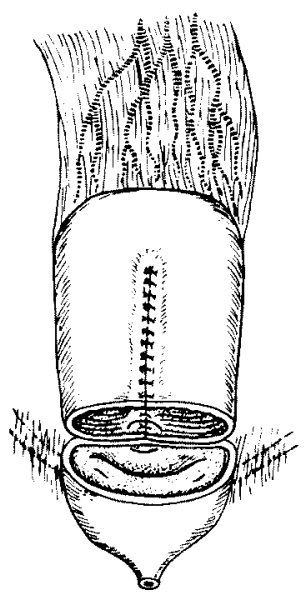

Fig. 7.

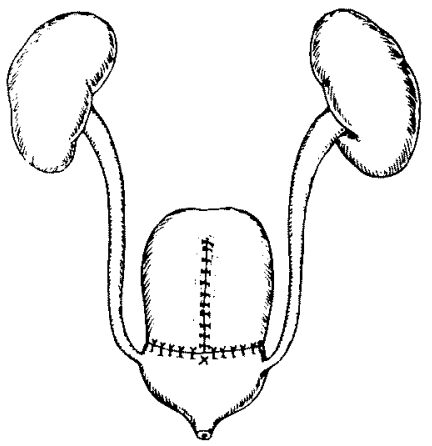

Fig. 8.

Fig. 7. Position of ileal segment, formed into a bag, relative to bladder. 
using fine catgut. Thereupon, as shown in Fig. 4, the mucous membrane at the cut-edge of the intestinal canal are closely stitched together by a continuous suture, using fine catgut. As shown in Fig. 5, a similar suture of the mucous membrane is made between the forehand intestinal walls that face each other, and then the forceps are removed after it has been ascertained that no bleeding occurs. Following this, the serous membranes are sutured. Thus, a bag of the intestinal canal is prepared, as illustrated in Fig. 6. In the next step, the bladder wall is exposed by exfoliation and cut open in order to make an anastomosis with the isolated intestinal canal. It is desirable that the area of the bladder to be anastomosed is as wide as possible. Then, the previously formed capsule of the intestinal canal is pulled down to the bladder, as shown in Fig. 7, and stitched to it, so that the cut-edges of the intestinal canal and those of the bladder come firmly into contact with each other. Fig. 8 is a diagrammatic illustration of an artificial bladder completed by our technique of ileocytoplasty. The peritoneum must then be closed with the newly formed bladder left outside. For this purpose, a nodular suture is made between the peritoneum and the mesentery attached to the intestinal canal which has been anastomosed to the bladder.

\section{Results AND Discussion}

As shown in Table 1, five cases were examined; four cases of contracted tuberculous bladder and one case of neurogenic bladder. All the tuberculous bladder cases complained of serious pollakiuria as a result of the contracted bladder due to urinary-tract tuberculosis. We have tried to increase the bladder capacity by intestinal cystoplasty in order to lessen the frequency of micturition. Case 3 had suffered from a contracted bladder since the left nephrectomy was performed in 1957. At the time of admission, urethral stricture was demonstrated, and the patient complained of micturition difficulty and of small amounts of urine passed. On $\mathrm{x}$-ray examination, the right renal pelvis was seen to be severely enlarged. The renal function was markedly lowered, being 15 $\%$ in the 30-minute value of the PSP test. Thereupon, renal drainage was first conducted to change the route of urine transportation, and then the urethral stricture was relieved by the external urethrotomy. Next, ileocystoplasty was performed 6 months after the renal function had been improved.

Case 5 with neurogenic bladder had undergone an operation for meningocele on the 23rd day after birth, and had since complained of pollakiuria and urinary incontinence. Various examinations revealed that the patient had a spastic bladder due to functional disturbance of the sacral anterior roots and was in a state of urinary incontinence under constant stimulations of micturition because the bladder had only a $50 \mathrm{ml}$ capacity. Thereupon, ileocystoplasty was tried to increase the bladder capacity. The findings obtained from the tests prior to and 1 to 2 months after the operation are presented in Tables 2-4. 
Table 1. Cases

\begin{tabular}{|c|c|c|c|c|c|}
\hline $\begin{array}{l}\text { Case } \\
\text { No. }\end{array}$ & Age & Diagnosis & Chief complaints & Past history & $\begin{array}{c}\text { Date of } \\
\text { operation }\end{array}$ \\
\hline 1 & 32 & $\begin{array}{l}\text { Tuberculous } \\
\text { contracted } \\
\text { bladder }\end{array}$ & Pollakiuria & $\begin{array}{l}\text { Suffered from bilateral } \\
\text { renal tuberculosis } \\
\text { since } 1958\end{array}$ & $\begin{array}{r}\text { Mar. } 22, \\
1960\end{array}$ \\
\hline 2 & 23 & " & & $\begin{array}{l}\text { Treated for renal tuber- } \\
\text { culosis since } 1956\end{array}$ & $\begin{array}{r}\text { Jun. } 23, \\
1960\end{array}$ \\
\hline 3 & 32 & & $\begin{array}{l}\text { Pollakiuria plus } \\
\text { dysuria }\end{array}$ & $\begin{array}{l}\text { Left nephrectomy in } \\
1957 \text {, renal drainage } \\
\text { and external urethro. } \\
\text { tomy in } 1961\end{array}$ & $\begin{array}{r}\text { Jan. } 18, \\
1962\end{array}$ \\
\hline 4 & 22 & & $\begin{array}{l}\text { Pollakiuria plus } \\
\text { dysuria }\end{array}$ & $\begin{array}{l}\text { Left kidney resected } \\
\text { for renal tuberculosis } \\
\text { in } 1955\end{array}$ & $\begin{array}{l}\text { May 24, } \\
\qquad 1961\end{array}$ \\
\hline 5 & 6 & $\begin{array}{l}\text { Neurogenic } \\
\text { bladder }\end{array}$ & $\begin{array}{l}\text { Pollakiuria plus } \\
\text { urinary } \\
\text { incontinence }\end{array}$ & $\begin{array}{l}\text { Pollakiuria existing } \\
\text { since birth. Opera- } \\
\text { tion for meningocele } \\
\text { on the } 23 \mathrm{rd} \text { day of } \\
\text { birth }\end{array}$ & $\begin{array}{r}\text { May 31, } \\
1960\end{array}$ \\
\hline
\end{tabular}

TABLE 2. State of micturition

\begin{tabular}{c|c|c|c|c}
\hline \multirow{2}{*}{ Case No. } & \multicolumn{2}{|c|}{ Bladder capacity $(\mathrm{ml})$} & \multicolumn{2}{c}{ Frequency of micturition } \\
\cline { 2 - 5 } & Before operation & After operation & Before operation & After operation \\
\hline 1 & 50 & 260 & 40 & 10 \\
2 & 130 & 300 & 18 & 7 \\
3 & 50 & 350 & 50 & 6 \\
4 & 200 & 300 & 16 & 15 \\
5 & 50 & 130 & Incontinence & \\
\end{tabular}

As shown in Table 2, the bladder capacity recovered its normal level or increased in all cases, the frequency of micturition decreased remarkably.

It has been said that the operation for anastomosing the intestinal canal to the bladder occasionally causes post-operative disturbances of renal function or abnormality of the blood components, since there is the possibility that the urine components are reabsorbed from the mucosa of the grafted intestinal canal. However, McLean et al., ${ }^{4}$ David et al. ${ }^{5}$ and others reported that when the length of the ileum segment to be used as an intestinal graft was limited to $30 \mathrm{~cm}$ or less such disturbances could be prevented. In our cases also, the ileum employed for grafting was less than $30 \mathrm{~cm}$ in length. Consequently, we have encountered few cases of post-operative ill effects; the conditions of all patients were benefited significantly after the operation. As shown in Table 3 , intravenous pyelograms were improved in Cases 1 and 3 ; and the 30-minute value of the PSP excretion test was improved in Cases 1,2 and 3. The maximum specific gravity of urine was the same before and after the operation, and the blood NPN level showed a 
TABLe 3. Renal function

\begin{tabular}{|c|c|c|c|c|c|c|c|c|}
\hline \multirow{2}{*}{$\begin{array}{l}\text { Case } \\
\text { No. }\end{array}$} & \multicolumn{2}{|c|}{ Intravenous pyelograms } & \multicolumn{2}{|c|}{$\begin{array}{c}\text { PSP test } \\
(30-\text { min. } \%)\end{array}$} & \multicolumn{2}{|c|}{$\begin{array}{l}\text { Maximum spec. } \\
\text { gravity of urine }\end{array}$} & \multicolumn{2}{|c|}{$\begin{array}{l}\text { Blood NPN } \\
(\mathrm{mg} / 100 \mathrm{ml})\end{array}$} \\
\hline & $\begin{array}{l}\text { Before } \\
\text { operation }\end{array}$ & After operation & $\begin{array}{l}\text { Before } \\
\text { oper. }\end{array}$ & $\begin{array}{l}\text { After } \\
\text { oper. }\end{array}$ & $\begin{array}{l}\text { Before } \\
\text { oper. }\end{array}$ & $\begin{array}{l}\text { After } \\
\text { oper. }\end{array}$ & $\begin{array}{l}\text { Before } \\
\text { oper. }\end{array}$ & $\begin{array}{l}\text { After } \\
\text { oper. }\end{array}$ \\
\hline 1 & $\begin{array}{l}\text { Both kidneys } \\
\text { moderately } \\
\text { enlarged }\end{array}$ & $\begin{array}{l}\text { Both kidneys } \\
\text { mildly } \\
\text { enlarged }\end{array}$ & 30 & 35 & 1030 & 1030 & 32.1 & 23.1 \\
\hline 2 & $\begin{array}{l}\text { Rright kidney } \\
\text { mildly } \\
\text { enlarged }\end{array}$ & $\begin{array}{l}\text { Right kidney } \\
\text { mildly } \\
\text { enlarged }\end{array}$ & 35 & 40 & 1032 & 1032 & 30.3 & 25.1 \\
\hline 3 & $\begin{array}{l}\text { Right kidney } \\
\text { seriously } \\
\text { enlarged }\end{array}$ & $\begin{array}{l}\text { Right kidney } \\
\text { moderately } \\
\text { enlarged }\end{array}$ & 30 & 33 & 1028 & 1030 & 39.0 & 31.5 \\
\hline 4 & $\begin{array}{l}\text { Right kidney } \\
\text { seriously } \\
\text { enlarged }\end{array}$ & $\begin{array}{l}\text { Right kidney } \\
\text { seriously } \\
\text { enlarged }\end{array}$ & 29 & 29 & 1028 & 1028 & 36.5 & 31.5 \\
\hline 5 & $\begin{array}{l}\text { Both kidneys } \\
\text { normal }\end{array}$ & $\begin{array}{l}\text { Both kidneys } \\
\text { normal }\end{array}$ & 42 & 40 & 1032 & 1032 & 31.0 & 32.0 \\
\hline
\end{tabular}

TABLE 4. Serum electrolytes

\begin{tabular}{c|c|c|c|c|c|c}
\hline \multirow{2}{*}{ Case No. } & \multicolumn{2}{|c|}{$\mathrm{K}(\mathrm{mEq} / l)$} & \multicolumn{2}{c|}{$\mathrm{Na}(\mathrm{mEq} / l)$} & \multicolumn{2}{c}{$\mathrm{Cl}(\mathrm{mEq} / l)$} \\
\hline & $\begin{array}{c}\text { Before } \\
\text { oper. }\end{array}$ & $\begin{array}{c}\text { After } \\
\text { oper. }\end{array}$ & $\begin{array}{c}\text { Before } \\
\text { oper. }\end{array}$ & $\begin{array}{c}\text { After } \\
\text { oper. }\end{array}$ & $\begin{array}{c}\text { Before } \\
\text { oper. }\end{array}$ & $\begin{array}{c}\text { After } \\
\text { oper. }\end{array}$ \\
\hline 1 & 5.2 & 4.3 & 145 & 145 & 97 & 95 \\
2 & 3.8 & 4.7 & 145 & 145 & 103 & 102 \\
3 & 4.3 & 4.3 & 145 & 143 & 108 & 105 \\
4 & 4.5 & 4.3 & 144 & 142 & 103 & 105 \\
5 & 5.0 & 5.2 & 143 & 142 & 99 & 98
\end{tabular}

tendency toward improvement.

The blood electrolytes remained, as seen in Table 4, almost invariable throughout the pre-operative and the post-operative periods, except that the serum chloride value was a little higher than normal in Case 3.

\section{References}

1) Scheele, K. Ueber Vergrösserungsplastik der narbigen Schrumpfblase. Beitr. klin. Chir., 1923, 129, 414-422.

2) Tasker, J.H. Ileo-cystoplasty: A new technique. A experimental study with report of a case. Brit. J. Urol., 1953, 25, 349-357.

3) Goodwin, W.E., Winter, C.C. \& Barker, W.F. "Cup-patch" technique of ileocystoplasty for bladder enlargement or partial substitution. Surg. Gynec. Obstet., 1959, 108, 240-244.

4) McLean, D.W. \& Fais, O.G. The use of segments of small intestine as ureters. $J$. Urol., 1952, 68, 190-200.

5) David, A.M. \& Bellwin, A. Experimental construction of an artificial bladder with maintenance of normal urinary function and continence. Ann. Surg., 1954, 139, $484-493$. 